\title{
Motivations and barriers to the adoption of green supply chain practices among 3PLs
}

\author{
Sara Perotti*, Guido J.L. Micheli and \\ Enrico Cagno
}

Department of Management, Economics and

Industrial Engineering,

Politecnico di Milano,

Piazza Leonardo da Vinci, 32, 20133 Milan - Italy

Email: sara.perotti@polimi.it

Email: guido.micheli@polimi.it

Email: enrico.cagno@polimi.it

*Corresponding author

\section{Introduction}

Green supply chain management (GSCM) and green supply chain practices (GSCP) refer to a variety of activities and initiatives implemented by an organisation in an attempt to reduce their impact on the natural environment. As highlighted by Testa and Iraldo (2010), the reasons towards GSCM may be ethical and/or commercial (e.g., gaining a competitive advantage by signalling environmental concern). However, despite its growing diffusion and success, a number of factors are still hampering GSCM adoption by companies.

In recent years, GSCM and sustainability issues have been attracting rising attention among researchers and practitioners, basically due to increased environmental concerns and to an ever-competitive environment. As remarked by Min and Kim (2012), this growing interest sparked a series of new lines of research dealing with various supply chain activities that have important environmental implications, ranging from manufacturing to logistics and transportation.

Focussing on logistics and freight transportation, several sources (e.g., Davies et al., 2007; Marchet et al., 2009) agree that this industry is presently facing a rising competitive pressure, mostly due to a combination of factors, such as the ongoing process of globalisation and internationalisation, the increasing need for cost reduction and service improvement, and the progressively more severe constraints related to the external environment. To address these requirements, the logistics service industry has 
gradually evolved from a single-activity towards a business model based on providing a wider range of integrated services, and third party logistics providers (3PLs) are currently playing a more critical role in their supply chains than in the past. In this evolving scenario, GSCP have been gaining in importance for 3PLs, as they need to support efforts aimed at improving the environmental sustainability of supply chain operations (e.g., Jumadi and Zailani, 2010; Evangelista et al., 2011). Although some recent studies have focussed on 3PL environmental sustainability, a need for further research in this area has been identified (Colicchia et al., 2010; Evangelista et al., 2011). In particular, key issues such as the reasons for the adoption of GSCP, as well as potential barriers to the adoption, would need further attention.

In order to address the gaps identified in the extant literature and building on previous research on green issues (e.g., Zhu and Sarkis 2006; Zhu et al., 2007; Lin and Ho, 2008), this study aims to empirically investigate the rationales behind the adoption of GSCP among 3PLs and to discuss the potential hurdles that may prevent companies from adopting such practices.

The remainder of this paper is organised as follows. The literature is reviewed in Section 2. The research objectives are presented in Section 3. The research methodology is described in Section 4, followed by findings and discussion in Section 5. Conclusions and future research directions are provided in Section 6.

\section{Literature review}

\subsection{Definition and scope of GSCM and practices}

Even if a widely-recognised definition of green supply chain is still lacking (Klassen and Johnson, 2004; Vachon, 2007), the existing literature acknowledges that GSCM is increasingly widespread among companies that are seeking to improve their environmental performance (Testa and Iraldo, 2010). A number of definitions can be found in the GSCM area. Traditionally, the definition and scope of GSCM in the literature has ranged from green purchasing to integrated green supply chains, and reverse logistics (Zhu et al., 2008; Setaputra and Mukhopadhyay, 2010), and it roots in both environmental management and supply chain management literature (Srivastava, 2007). A recent and more holistic definition of GSCM is provided by Sundarakani et al. (2010), who describe it as "the integration of environmental thinking into supply chain management, including product design, supplier selection and material sourcing, manufacturing processes, product packaging, delivery of the product to the consumers, and end-of-life management of the product after its use". As such, GSCM ranges from green product design to a closed loop product return processing, and requires high-level and detailed planning and steering of complete supply chains on an end-to-end basis.

Previous contributions have discussed both general environmental management issues within the supply chain (e.g., Hall, 2000; Zhu and Sarkis, 2004; Gonzalez-Benito and Gonzalez-Benito, 2006; Vachon and Klassen, 2006; Vachon, 2007; Zhu et al., 2007; Zhu et al., 2008), and specific green facets of supply chain management such as green design (Diwekar and Shastri, 2010), production planning and control for remanufacturing (Guide et al., 1999), green manufacturing (Smith, 2012), product recovery (Gungor and Gupta, 1998), reverse logistics (Cagno et al., 2008), and logistics network design (Jayaraman et al., 2003; Lee and Dong, 2009). 
Within the broad concept of GSCM, GSCP refer to a variety of activities and initiatives implemented by an organisation in an attempt to reduce their impact on the natural environment (Awaysheh and Klassen, 2010; Sarkis et al., 2010). According to Vachon and Klassen (2006), GSCP encompass both internal and external activities, whether related to preventing pollution before it is generated, recycling waste and spent products, extracting resources and raw materials, or capturing harmful pollutants followed by proper disposal. In a slightly different way of clustering, Zhu et al. (2007) have broken down the examined GSCP into: internal environmental management; green purchasing; customer cooperation with environmental concerns; investment recovery; and, eco-design dimensions. Whatever definition of GSCP is considered, a potential impact of GSCP on company performance is nowadays widely acknowledged, including environmental, economic and operational performance (Zhu et al., 2007; Sundarakani et al., 2010).

\subsection{GSCPs among $3 P L s$}

The literature on this topic has been recently reviewed by Marasco (2008). Overall, an increasing number of contributions have focused on 3PLs so far (e.g., Ansari and Modarress, 2010; Shi and Arthanari, 2011), and this reflects the increasing popularity of logistics outsourcing and the subsequent growth of 3PL services.

Several definitions of 3PLs have been provided in the literature. For instance, Hertz and Alfredsson (2003) define a 3PL as 'an external provider who manages, controls, and delivers logistics activities on behalf of a shipper'. The activities performed can include all (or a part of) the logistics activities, but at least management and execution of transportation and warehousing.

Some contributions in the existing GSCM literature have specifically analysed logistics practices (e.g., Zhu et al., 2008; Rai et al., 2011). In particular, the term 'green logistics' has been also adopted when referring to environmental issues related to sustainable transportation, hazardous material handling and storage, inventory control, warehousing, packaging, and facility location-allocation decisions that aim to reduce carbon footprint (Min and Kim, 2012). As such, a number of green practices have been examined, including reverse logistics (e.g., Cagno et al., 2008) and logistics network design (e.g., Jayaraman et al., 2003; Lee and Dong, 2009). Further examples involve warehousing and green building issues (e.g., Murphy and Poist, 2000; Hervani and Helms, 2005; Lin and Ho, 2008; Jumadi and Zailani, 2010; Rai et al., 2011), as well as distribution and transportation execution (e.g., Lin and Ho, 2008; Langella and Zanoni, 2011).

Interesting studies focussing on sustainability issues among 3PLs have been also found (e.g., Wolf and Seuring, 2010; Lieb and Lieb, 2010). Still, there seems to be a need to further investigate GSCP in relation to the idiosyncrasies of 3PLs (Perotti et al., 2012).

\subsection{Motivations and barriers to GSCP}

As far as motivations towards adoption are concerned, previous literature (e.g., Walker et al., 2008; Testa and Iraldo, 2010; Large and Gimenez Thomsen, 2011; Diabat and Govindan, 2011; Wiengarten et al., 2013) has discussed a number of factors that may influence company responsiveness to the implementation of GSCP. For instance, Xu et al. (2013) have identified different pressures and classified them into five groups (i.e., 
government policies and regulations, marketability of the product and competitiveness, external factors in the supply chain, financial factors, production and operational factors) based on their similarities.

Overall, various contributions in the extant literature identify motivations towards GSCP that can be classified into external and internal. As an example, Zhu et al. (2007) have mentioned a number of external factors, such as the role of institutional pressures, as possible reasons why companies should engage in environmental initiatives. Legislative and regulatory compliance has been recognised by other authors as one of the potential drivers to implementation (e.g., Zhu and Sarkis, 2007; Lieb and Lieb, 2010). Further identified external motivations include: pressure by customers/marketing or explicit customer demand (Murphy and Poist, 2000; Hervani and Helms, 2005; Gonzalez-Benito and Gonzalez-Benito, 2006; Zhu and Sarkis, 2007; Lin and Ho, 2008; Lieb and Lieb, 2010); competitive pressures (Lieb and Lieb, 2010); public pressure and societal expectations (Murphy and Poist, 2003); collaboration with suppliers (Vachon and Klassen 2006); and profit opportunities (Murphy and Poist, 2003; Wolf and Seuring, 2010).

Besides external factors, a number of internal (i.e., company-related) drivers can be identified in relation to sustainability initiatives, such as: improvement of company environmental performance (e.g., McIntyre and Smith, 1998; Gonzalez-Benito and Gonzalez-Benito, 2006; Lieb and Lieb, 2010); efficiency increase and cost reduction (e.g., Wu and Dunn, 1995; Vachon, 2007; Wolf and Seuring, 2010; Zailani et al., 2010); willingness to gain competitive advantage (Sarkis, 2003; Murphy and Poist, 2003); and company reputation (Lin and Ho, 2008). Among the most important reasons for establishing sustainability programmes, Lieb and Lieb (2010) also mention the 'corporate desire to do the right thing'. Focussing on 3PLs, the adoption of green practices seems to be largely driven by economic motivations, and a pure environmental perspective is rarely observed among 3PLs (e.g., Perotti et al., 2012). However, as consumers demand greener alternatives and environmental regulatory measures are implemented, 3PLs will have to become more environmentally and socially aware in order to meet sustainability goals (Facanha and Horvath, 2005).

Looking at the barriers that may prevent companies from adopting GSCP (e.g., Mudgal et al., 2010), Govindan et al. (2013) have identified five main categories, namely: outsourcing (e.g., lack of government support to adopt environmental friendly policies, complexity of measuring/monitoring suppliers' environmental practices); technology (e.g., lack of technical expertise, lack of human resource, lack of effective environmental measures); knowledge (e.g., lack of environmental knowledge, perception of 'out-of-responsibility' zone, disbelief about environmental benefits); financial (e.g., financial constraints, non-availability of bank loans to encourage green products/processes, high investments and less return-on-investments); and involvement and support (e.g., lack of customer awareness and pressure about GSCM, lack of corporate social responsibility, lack of top management involvement in adopting GSCM, poor supplier commitment).

In general, both internal and external factors can be identified. Focussing on internal barriers, companies seem to be hampered by economic or financial factors. Such is the case of the emerged difficulty in taking on investment risk (e.g., McKinnon, 2010), especially when no incentives for sustainable supply chain management are available (Zhu and Sarkis, 2007). Besides, there is great difficulty in quantifying the costs coming from adoption (McKinnon, 2010). A second element that seems to act as an obstacle lies 
in the long implementation periods especially for small-sized 3PLs, as observed by Lieb and Lieb (2010). Third, a general lack of awareness has been remarked (e.g., Muduli et al., 2013): the investment is sometimes not perceived as being necessary, and this prevents companies from implementation (Wolf and Seuring, 2010). Fourth, companies seem to perceive some operational challenges, mostly due to personnel training (e.g., Hervani and Helms, 2005) or a lack of knowledge (Wolf and Seuring, 2010). Connected to this latter point, a general reluctance to change has also been observed (Sarkis, 2003; McKinnon, 2010).

As far as external barriers are concerned, inhibition towards innovation and lack of knowledge has been identified (e.g., Hervani and Helms, 2005). Lack of integration among players in the supply chain (i.e., suppliers and customers), and specifically the scarce attitude towards collaboration, has also been identified by Vachon and Klassen (2006).

A summary of the main motivations and barriers to GSCP adoption is presented in Table 1.

Table 1 Summary of main motivations and barriers to GSCP identified in the literature

\begin{tabular}{|c|c|c|c|}
\hline & & Type & Main references \\
\hline \multirow[t]{12}{*}{ Motivations } & \multirow[t]{8}{*}{ External } & Role of institutional pressures & \multirow{8}{*}{$\begin{array}{l}\text { Zhu et al. (2007), Murphy and } \\
\text { Poist (2000), Sarkis (2003), } \\
\text { Murphy and Poist (2003), } \\
\text { Hervani and Helms (2005), } \\
\text { Gonzalez-Benito and Gonzalez- } \\
\text { Benito (2006), Vachon and } \\
\text { Klassen (2006), Zhu and Sarkis } \\
\text { (2007); Lin and Ho (2008) and } \\
\text { Lieb and Lieb (2010) }\end{array}$} \\
\hline & & Legislative and regulatory compliance & \\
\hline & & Public pressure and societal expectations & \\
\hline & & Pressure by customers/marketing or & \\
\hline & & explicit customer demand & \\
\hline & & Collaboration/ integration with suppliers & \\
\hline & & $\begin{array}{l}\text { Competitive pressures and desire to gain } \\
\text { competitive advantage }\end{array}$ & \\
\hline & & Improve company 'green' image & \\
\hline & \multirow[t]{4}{*}{ Internal } & Company environmental improvement & \multirow{4}{*}{$\begin{array}{c}\text { Wu and Dunn (1995), McIntyre } \\
\text { and Smith (1998), Murphy and } \\
\text { Poist (2003), Gonzalez-Benito } \\
\text { and Gonzalez-Benito (2006), } \\
\text { Vachon (2007), Lieb and Lieb } \\
\text { (2010), Wolf and Seuring } \\
\text { (2010) and Zailani } \\
\text { et al. (2010) }\end{array}$} \\
\hline & & Company environmental mission & \\
\hline & & Commitment of top-level management & \\
\hline & & Efficiency increase and cost reduction & \\
\hline \multirow[t]{13}{*}{ Barriers } & \multirow[t]{9}{*}{ Internal } & Difficulty in taking on investment risk & \multirow{9}{*}{$\begin{array}{l}\text { Sarkis (2003), Hervani and } \\
\text { Helms (2005), Lieb and Lieb } \\
\text { (2010), McKinnon (2010) and } \\
\text { Wolf and Seuring (2010) }\end{array}$} \\
\hline & & Difficulty in quantifying the costs coming & \\
\hline & & from adoption & \\
\hline & & Long implementation periods & \\
\hline & & Lack of awareness & \\
\hline & & Investment not perceived as necessary & \\
\hline & & Personnel training & \\
\hline & & Lack of knowledge & \\
\hline & & Reluctance to change & \\
\hline & \multirow[t]{4}{*}{ External } & Inhibition towards innovation & \multirow{4}{*}{$\begin{array}{l}\text { Hervani and Helms (2005) and } \\
\text { Vachon and Klassen (2006) }\end{array}$} \\
\hline & & Lack of knowledge & \\
\hline & & $\begin{array}{c}\text { Lack of integration amongst the players of } \\
\text { the supply chain }\end{array}$ & \\
\hline & & Scarce attitude towards collaboration & \\
\hline
\end{tabular}




\section{Research questions}

Due to the still limited amount of research conducted in this area so far, the results presented in Table 1 lack a specific focus on the 3PLs. In fact, because of their specific characteristics, it is likely to suppose that some of the GSCM motivations and barriers previously identified could be not suitable for 3PLs, or else, additional factors should be taken into account.

Therefore, the aim of this study is to empirically investigate the motivations and barriers to GSCP adoption among 3PLs. Based on previous work conducted on green issues (Zhu et al., 2007, 2008; Lin and Ho, 2008), this paper aims to answer the following research questions:

- RQ1: What are the main motivations towards GSCP adoption among 3PLs?

- RQ2: What are the barriers to GSCP adoption among 3PLs?

In line with the previous part of the broader research project on GSCM issues among 3PLs (Perotti et al., 2012), to which this study belongs, we focussed on 3PLs operating in Italy. The Italian context of 3PLs is particularly challenging (Perotti et al., 2012), as it presents a strong fragmentation, with multiple levels of sub-contracting and a myriad of small, poorly integrated companies, with a still low pervasiveness of green practices - although increasing with respect to the past. Due to this fact, it has been only partially tackled by previous GSCM literature.

\section{Methodology}

Given the explorative nature of the study, the research has been carried out as case-studies using semi-structured interviews and questionnaires. In particular, 15 case studies were conducted with 3PLs operating in different supply chains (e.g., chemicals, food, pharmaceuticals) in Italy.

\subsection{Multi-case selection procedure}

As recommended in multiple case empirical research (e.g., Eisenhardt, 1989; Yin, 2009), the case selection was aimed at achieving replication in order to support the generalisability of our results. In accordance with Marchet et al. (2009), the starting point was a set of databases provided by Italian statistical sources (e.g., ISTAT) and other research institutes (e.g., Confetra, the Italian association of companies operating in the logistics and transportation sector). Four main selection criteria have been taken into account for the companies to be included:

1 companies operating in different supply chains (identified as a potentially relevant factor by Zhu et al. (2007)

2 different company size

3 different enterprise structures (i.e., groups vs. independent companies)

4 willingness to participate in the research project. 
Table 2 Characteristics of companies interviewed and the supply chains/industry sectors they are involved in (the last row refers to the prospective supply chain in which companies are strategically interested)

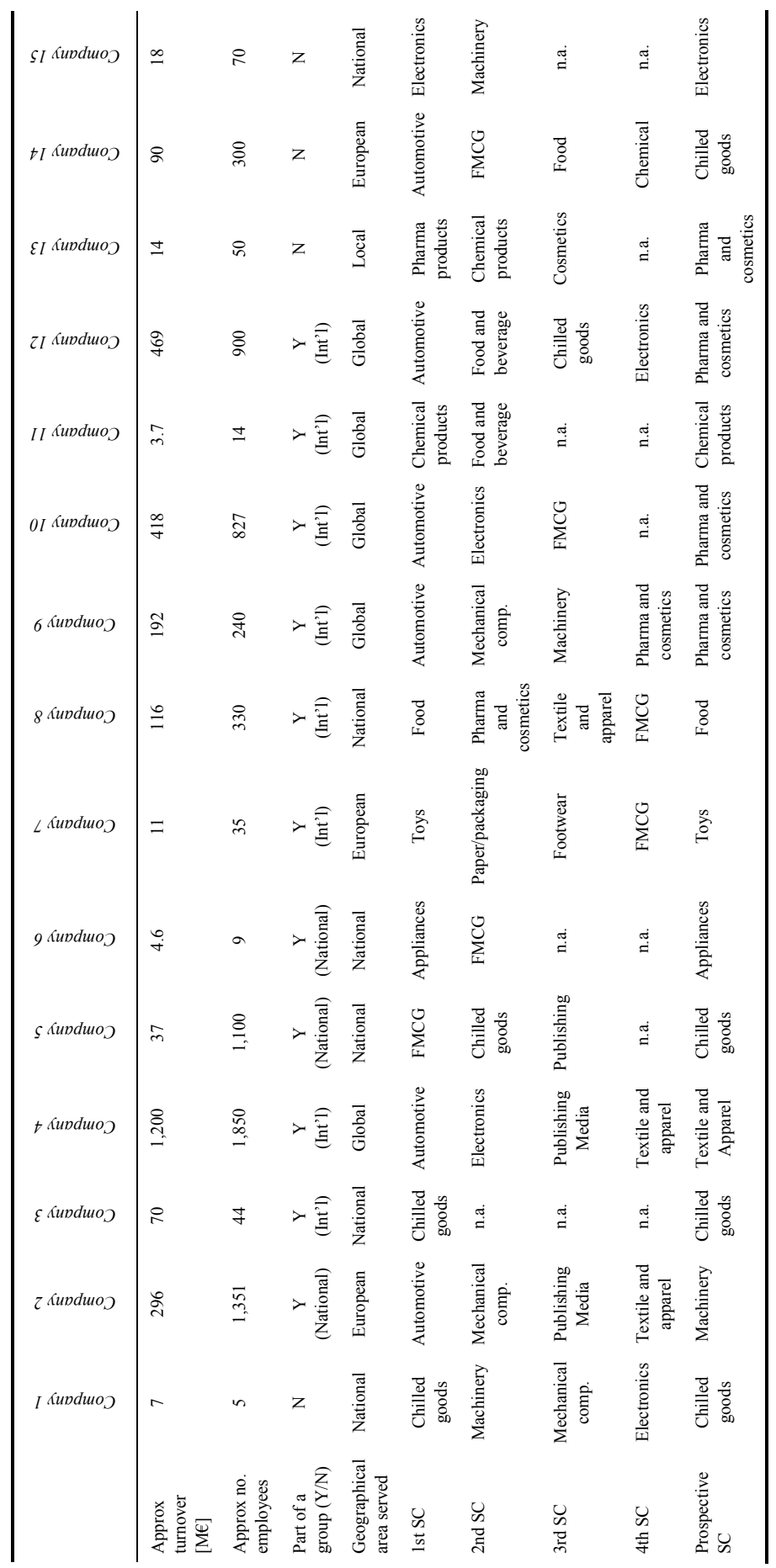


Table 2 provides a summary of the sample features (in the following, we will refer to the definition in the 2003/361/EC Recommendation as for small-, $\leq 50$ employees, medium-, $50<$ employees $\leq 250$, and large-sized companies, $>250$ employees), including information on the supply chains to which the examined companies belong. This table also includes information about the prospective supply chain(s) in which the companies have declared to be strategically interested for the near future.

\subsection{Data collection and analysis}

The case studies have been structured as follows. First, the respondents (i.e. managing directors, operations managers, logistics managers of the 15 selected companies) were asked to fill out a guided questionnaire covering various aspects of GSCM. Questions were organised into five main sections. As this research is part of a larger research project, only three of the sections included in the questionnaire are relevant to this paper. The first section included general information on the interviewee and the company, such as company profile, level of turnover, length of business operations (Lai, 2004), geographical area served (Hertz and Alfredsson, 2003; Wanke et al., 2007), type of industry served (Wanke et al., 2007). The second section encompassed questions regarding company business details, such as type of service provided, asset ownership characteristics, use of Information Technology (IT) (Hertz and Alfredsson, 2003; Wanke et al., 2007). A specific section was devoted to questions on motivations and barriers to the adoption of GSCP.

Afterwards, the respondents were interviewed and provided further details on the responses provided, as well as their view about sustainability issues and GSCP. During the interviews, the authors obtained the interviewees' additional comments on the main motivations and barriers to GSCP adoption. The set of factors emerged from the literature review was first investigated, and additional factors were included when significant.

A case study database was created and detailed case study reports were prepared and then reviewed by the interviewees. Data triangulation was achieved by the collection and analysis of secondary data (i.e., from company websites).

Data analysis (i.e., within- and cross-case) was performed for each case following the approach described by Voss et al. (2002). Within-case analysis was performed by writing a detailed report for each case according to the constructs used in the data collection (Eisenhardt, 1989), and classifying the data collected on motivations and barriers for each case according to a descriptive scale (not relevant; moderately relevant; extremely relevant). A cross-case analysis was then performed to identify common patterns, categorising data as they were collected (Miles and Huberman, 1994), so as to force the investigation to go beyond initial impressions (Eisenhardt, 1989).

\subsection{Methodology validity and reliability}

To guarantee methodological rigour, issues concerning construct validity, internal validity, external validity and reliability were addressed within this research project, as suggested by Ellram (1996) and Yin (2003). First, construct validity refers to establishing appropriate operational measures for the concepts being studied. For this purpose, interviews were audio-recorded and transcribed to aid analysis before detailed reports were drafted and reviewed by the interviewees. The questionnaire was also supplemented by the collection and analysis of secondary data (Voss et al., 2002), such as from 
company websites and reports. Second, internal validity, i.e. the extent to which causal relationships can be established, was achieved through pattern matching during the data collection. Third, external validity refers to the domain to which the findings may be generalised. Generalisability was enhanced by selecting cases displaying different characteristics and operating in different supply chains, as recommended by Yin (2003). Finally, reliability refers to the extent to which research operations can be repeated with the same results and it was ensured by maintaining a case study database and by using a case study protocol.

\section{Results and discussion}

\subsection{Main motivations towards GSCP adoption}

Table 3 summarises our findings in terms of the motivations towards GSCP adoption (descriptive scale: not relevant = ' - '; moderately relevant = 'm'; extremely relevant $=$ 'E', as in Table 3). Such motivations are primarily related to coercive factors such as compliance with environmental regulations. From this perspective, national or regional environmental regulations seem to play a key role (13 ' $E$ ' and 1 ' $\mathrm{m}$ ' out of 15). Specifically, this aspect appears to be as one of the foremost drivers towards GSCP adoption for those companies that handle environmentally hazardous products (e.g., Company 11, dealing with pharmaceutical and chemical products).

Among customer-related factors, establishing a company green image has emerged as the most relevant factor (10 ' $\mathrm{E}$ ' and 3 ' $\mathrm{m}$ ' out of 15). Companies started perceiving GSCM as a key issue, feeling the need to become somehow 'green' and promoting themselves as 'green' or 'sustainable'. On the contrary, environmental requirements from domestic customers ( 8 ' $\mathrm{E}$ ' and 4 ' $\mathrm{m}$ ' out of 15), as well as environmental awareness of customers and consumers (9 ' $\mathrm{E}$ ' and 4 ' $\mathrm{m}$ ' out of 15), have been mentioned less frequently, presumably because of a still low interest/green awareness that prevents customers from perceiving a green $3 \mathrm{PL}$ as better than other non-green competitors. Supplier-related factors do not seem to be among the prevailing motivations towards GSCP adoption. Competitor-related factors appear to play a slightly more relevant role. The interviews with senior executives have also revealed that, while some players have shown a relatively proactive attitude, others seem to be more reactive, looking at competitors in order to decide what to do, and how, in terms of GSCP.

Focussing on internal factors, environmental reputation has emerged as the most relevant driver (12 ' $\mathrm{E}$ ' and 1 ' $\mathrm{m}$ ' out of 15 ), thus demonstrating that 3PLs operating in Italy are nowadays more concerned about GSCM than they used to be in the past. Furthermore, for some of the larger companies that belong to multinational groups, GSCM and sustainability issues are embodied in their company mission (11 ' $\mathrm{E}$ ' and 1 ' $\mathrm{m}$ ' out of 15). Another remarkable aspect is related to the commitment of top-level management (9 ' $E$ ' and 4 ' $m$ ' out of 15), in line with some previous findings (e.g., Zhu and Sarkis 2004). Finally, both potential liability (11 'E' and 1 ' $\mathrm{m}$ ' out of 15) and company environmental mission ( 10 ' $\mathrm{E}$ ' and 3 ' $\mathrm{m}$ ' out of 15 ) seem to be noteworthy motivations. 
Table 3 Motivations towards GSCP adoption

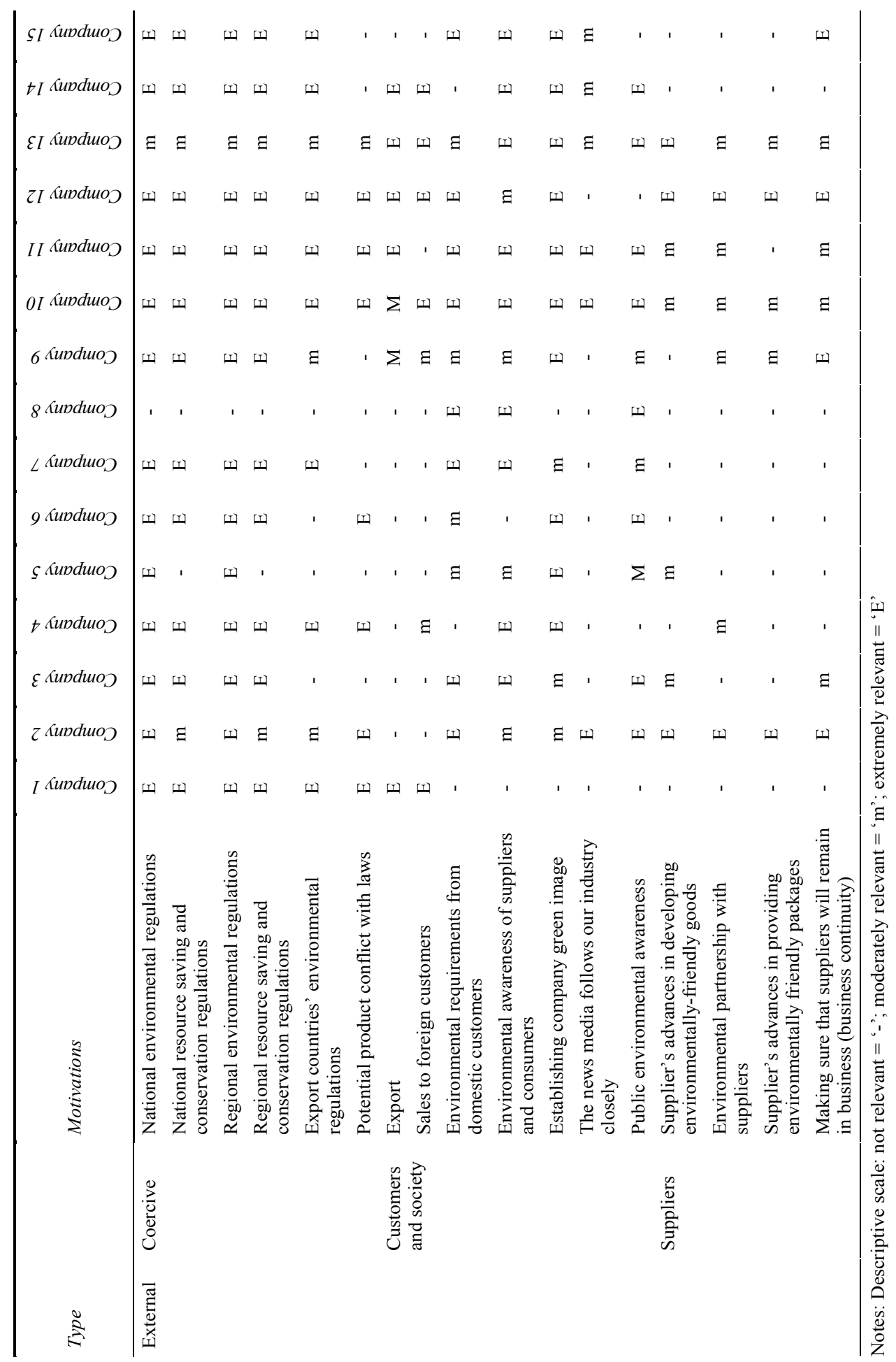


Table 3 Motivations towards GSCP adoption (continued)

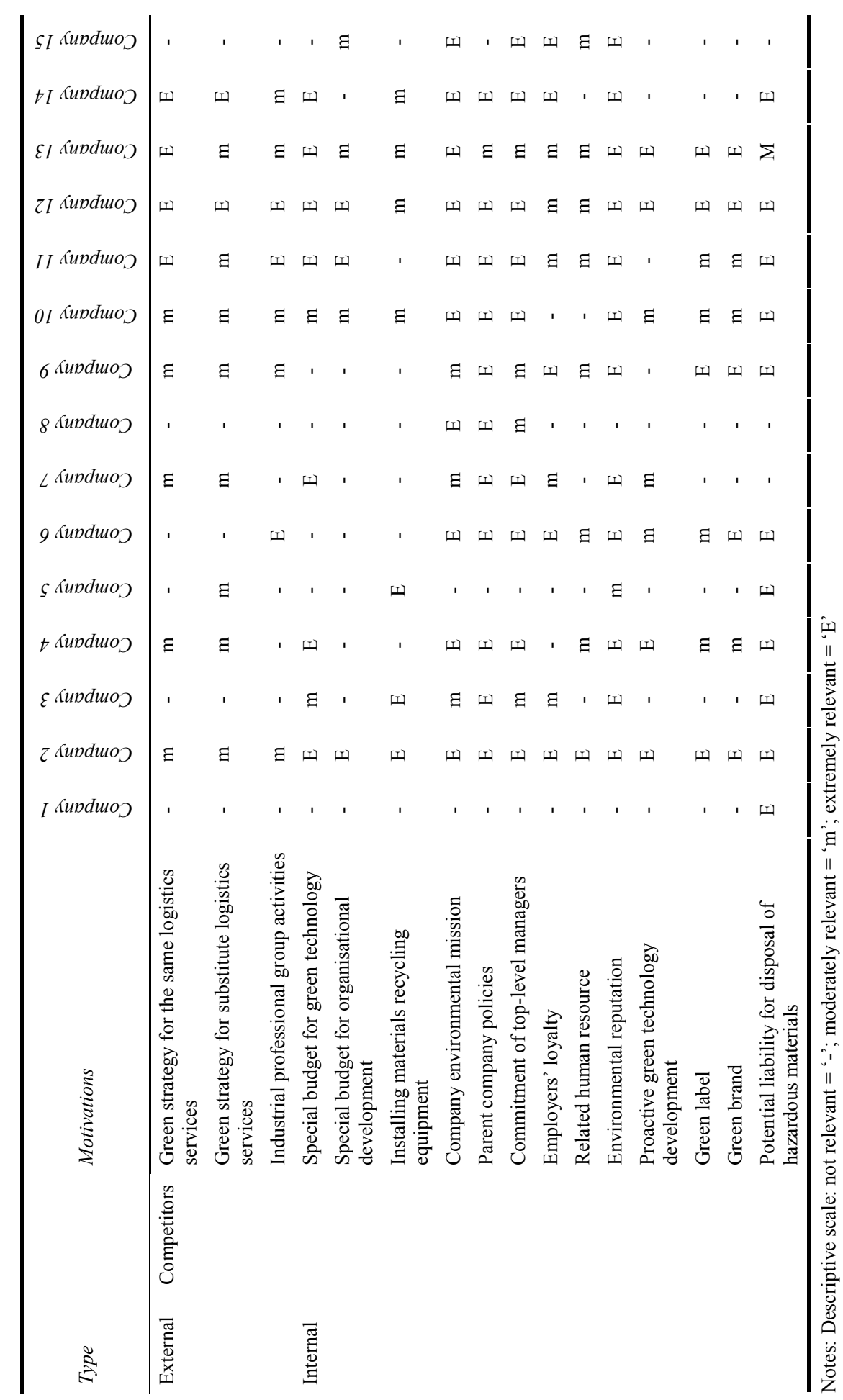




\subsubsection{Geographical area served}

Focussing on the geographical area served, the 3PLs that operate globally seem to be driven by both external and internal factors. As far as external factors are concerned, the main motivations towards GSCP adoption lie in coercive factors (i.e., regulations and normative constraints). This is consistent with some of the previous findings in the literature (e.g., Murphy and Poist, 2003; Zhu and Sarkis, 2007; Lieb and Lieb, 2010). In addition, improving company image is also an important driver based on our study. In terms of the internal factors, company environmental mission, parent company policies (i.e., for subsidiaries or divisions of multinational companies) as well as environmental reputation have emerged as relevant. A high commitment of top-level management has been also identified as important in the analysis. Additionally, potential liability seems to be a key driver.

The main motivations highlighted by the 3PLs operating at a European level mostly refer to national and regional regulations as far as external drivers are concerned. Internal factors, as in the case of the 3PLs operating globally, mainly include special budgets for green technology, parent company policies, environmental reputation and commitment of top-level management. The 3PLs operating on a national basis appear to be mostly driven by coercive motivations (i.e., compliance with the extant regulation). Company 13, which is the only 3PL in the sample that operates locally, seems to be mostly motivated by internal factors such as improving its environmental reputation, pursuing company environmental mission, green label, and green brand, and the interview has clearly showed an overall proactive green attitude.

\subsubsection{Types of supply chain/industry sectors}

Looking at the type of supply chain, those companies that are primarily involved in the automotive industry showed generally stronger motivations towards GSCP compared with the other companies in the sample. Among the external factors, their main focus is on coercive factors, namely national/regional environmental regulations. Establishing a company green image also appears to be important. As to the internal factors, parent company policies have emerged as one of the main drivers towards GSCP adoption. This aspect appears to be rather important, given the fact that those companies (Perotti et al., 2012) present the highest GSCP adoption level and better perceive a positive impact of the implemented GSCP on company performance. It seems as if the adoption of GSCP and the corresponding appreciation of their impact on the performance enable further motivations towards GSCP in a virtuous circle. Moreover, environmental regulations seem to represent a potential trigger for 'greening' the SCM, as they are among the main motivations towards GSCP.

Looking at the prospective supply chains, all the four companies that are strategically interested in pharmaceutical products identified establishing a company green image as a key motivation, as well as environmental reputation, followed by parent company policies and company environmental mission. Commitment of top-level management also appears to be important. Conversely, those four companies that are strategically interested in chilled goods for the near future seem to be mostly driven by coercive motivations, whereas proactive development of green technology, green labels and green brands are completely disregarded. 
Table 4 Barriers to GSCP adoption

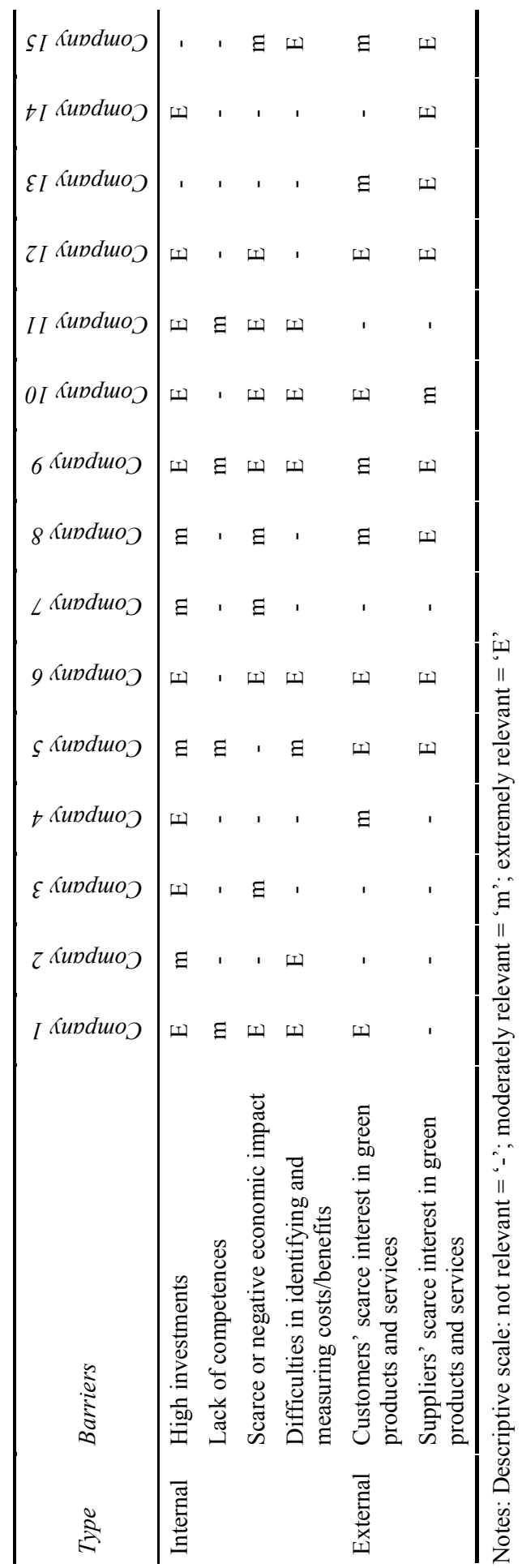


It is possible to highlight some patterns also from the viewpoint of supply chain stability. A company supply chain has been classified as 'unstable' when the prospective supply chain identified by the interviewee differs from all the current supply chains. Based on Table 2, four cases in the sample are characterised by unstable supply chains. For these cases, the adoption of GSCP appears to be driven by both internal (i.e., parent company policies and commitment of top-level managers) and external (i.e., coercive - national and regional environmental regulations) factors. Establishing a company green image and environmental reputation are also relevant drivers to the adoption. This is consistent with the fact that the companies interested in new supply chains usually tend to improve their reputation on several fronts in order to capture new customers and enter new markets. Companies whose prospective supply chain is the same as their fourth current supply chain show a very similar attitude. External (customer-related) factors, such as establishing a company green image, seem to be fundamental. In addition, internal factors such as parent company policies and potential liability for disposal of hazardous materials have also emerged as important drivers for companies 4 and 9.

Coercive factors such as national resource saving and conservation regulations and regional environmental regulations have emerged as crucial for those companies that are characterised by more stable supply chains.

\subsection{Barriers to GSCP adoption}

Table 4 summarises the main results in terms of the barriers to GSCP adoption (descriptive scale: not relevant $=$ '-'; moderately relevant $=$ ' $\mathrm{m}$ '; extremely relevant $=$ ' $\mathrm{E}$ ', as in Table 4).

Besides a need for high investments, suppliers' and customers' scarce interest in green products and services has been identified as a common feature, together with difficulties in identifying and measuring costs/benefits. In contrast with some of the previous findings (e.g., Zhu et al., 2008), lack of competences has not emerged as a primary barrier to GSCP adoption.

\subsubsection{Geographical area served}

Focussing on the geographical area served, the main barrier identified by the analysed 3PLs operating on either a global or European level seems to be economic in nature, i.e., high investments associated with the implementation of GSCP. This is consistent with the findings by McIntyre and Smith (1998). A scarce or negative economic impact also represents a key challenge for the 3PLs operating globally. In some cases a relevant barrier lies in the difficulties in identifying and measuring costs and benefits deriving from the adoption. This latter hurdle has been also highlighted by McKinnon (2010). 3PLs operating on a national level identified high investments, difficulties in identifying and measuring costs and benefits deriving from the adoption, customers' and suppliers' scarce interest in green products and services as equally important barriers to GSCP adoption. Company 13, which is the only local 3PL in the sample, highlighted poor supplier commitment as well as a scarce customer and supplier interest in green products and services, and this is the case more in line with Zhu and Sarkis (2007). Overall, results from the interviews showed a clear lack of integration amongst players in the supply chain, and specifically a scarce attitude towards inter-organisational collaboration in relation to GSCP. This seems consistent with the findings by Vachon and Klassen (2006). 


\subsubsection{Types of supply chain/industry sector}

In terms of types of supply chain, it is possible to identify some similarities among those companies that are primarily involved in the automotive industry. High investments have emerged as the most relevant barrier in almost all of the six cases. Although it is difficult to identify any clear patterns for the other companies in the sample, high investments have emerged as generally important.

Focussing on supply chain stability, high investments are definitely an important barrier for those companies that are characterised by unstable supply chains. On the contrary, lack of competences does not seem to be perceived as an obstacle to GSCP adoption; these companies generally feel confident about the flexibility required to deal with the changes associated with GSCP implementation. No clear patterns have emerged for those cases characterised by more stable supply chains. A number of barriers have been identified by the interviewees in all these cases, which seems to suggest a general lack of proactivity as well as a lack of understanding of the actual and main challenges. However, some exceptions have been highlighted. An example is provided by Company 5 , in the sense that customers' and suppliers' scarce interest in green products and services have clearly emerged as key aspects in influencing GSCP implementation.

\section{Conclusions}

This study illustrates the results of a broader research project (Perotti et al., 2012) and provides insights on motivations and barriers to the adoption of GSCP among 3PLs operating in Italy. The research has also identified in the geographical area served and in the degree of stability of a company supply chains two important explanatory factors that can help understand some of the differences in GSCP adoption identified among the analysed companies.

In general, the adoption of GSCP does not seem to be driven by competitive advantage solely based on sustainability, possibly because of a still scarce interest/low green awareness that prevent companies from perceiving green 3PLs as better than others 'non-green' competitors. However, the analysed companies have started perceiving GSCP as a key company image issue, feeling the need to become somehow 'green'. Specifically, environmental reputation and establishing a company green image have been identified as key motivations in our study. This is particularly true for those companies prospectively moving to different supply chains. On the contrary, coercive factors have emerged as important for those companies prospectively interested in more stable supply chains.

As far as barriers to GSCP adoption are concerned, high investments, suppliers' and customers' scarce interest in green products and services have been identified as common factors. Difficulties in identifying and measuring costs/benefits have also emerged as relevant based on our analysis. High investments are an important barrier particularly for those companies that are prospectively moving to different supply chains, whereas lack of competences does not seem to be perceived as an obstacle to GSCP adoption.

This study has both research and managerial implications. In terms of implications for future research, our results can be useful to understand motivations and barriers to GSCP adoption in relation to the distinguishing features of the 3PL industry, specifically within the Italian context, which is consistent with the call for research in this area by Colicchia 
et al. (2011). As far as managerial implications are concerned, what has emerged is the importance of a supply chain viewpoint to look at environmental sustainability issues. The findings of the present study are of interest to logistics managers in order to have a clearer understanding of GSCP adoption, help them evaluate the rationales behind the adoption of such practices, and to understand the drivers and challenges associated with their adoption.

This work is one of the few efforts to investigate GSCP in Italy. Thus, our investigation and its findings are still relatively exploratory. Additionally, our results have to be considered as specific to the Italian context, even though many companies of the sample operate globally and/or are part of international groups.

Nevertheless, we do believe that the results of the present research offer valuable insights for future investigation into green and sustainability issues involving 3PLs, fourth party logistics (4PLs), and logistics service providers (LSPs) on a global scale, and may pave the way for future research on this arena. In this sense, further studies on the role of supply chain and market features in impacting on motivations and barriers to GSCP adoption may be recommended. Future research should also analyse the relationship between drivers and challenges to the adoption, and actions that can be taken by companies in order to reduce the perceived barriers. Additionally, the evolutionary process of GSCP adoption over time should be studied in detail, thus to identify any leading trends, as well as allow potential cross-country comparisons. Finally, further investigation of the impact of GSCP on logistics processes would provide both interpretive and quantitative models (e.g., decision-support models) to measure the achievable benefits, to overcome adoption barriers, and to help managers to decide whether to invest in GSCP.

\section{References}

Ansari, A. and Modarress, B. (2010) 'Challenges of outsourcing logistics to third-party providers', International Journal of Logistics Systems and Management, Vol. 7, No. 2, pp.198-218.

Awaysheh, A. and Klassen, R.D. (2010) 'The impact of supply chain structure on the use of supplier socially responsible practices', International Journal of Operations \& Production Management, Vol. 30, No. 12, pp.1246-1268.

Cagno, E., Magalini F. and Trucco, P. (2008) 'Modelling and planning of product recovery network: the case study of end-of-life refrigerators in Italy', International Journal of Environment Technology and Manufacturing, Vol. 8, No. 4, pp.385-404.

Colicchia, C., Melacini, M. and Perotti, S. (2011) 'Benchmarking supply chain sustainability: insights from a field study', Benchmarking: An International Journal, Vol. 18, No. 5, pp.705-732.

Davies, I., Mason, R. and Lalwani, C. (2007) 'Assessing the impact of ICT on UK general haulage companies', International Journal of Production Economics, Vol. 106, No. 1, pp.12-27.

Diabat, A. and Govindan, K. (2011) 'An analysis of the drivers affecting the implementation of green supply chain management', Resources, Conservation and Recycling, Vol. 55, No. 6, pp.659-667.

Diwekar, U.M. and Shastri, Y.M. (2010) 'Green process design, green energy, and sustainability: a systems analysis perspective', Computers \& Chemical Engineering, Vol. 34, No. 9, pp.1348-1355.

Eisenhardt, K.M. (1989) 'Building theories from case study research', The Academy of Management Review, Vol. 14, No. 4, pp.532-550. 
Ellram, L. (1996) 'The use of case study method in logistics research', Journal of Business Logistics, Vol. 17, No. 2, pp.93-138.

Evangelista, P., Huge-Brodin, M., Isaksson, K. and Sweeney, E. (2011) 'The impact of 3PL's green initiatives on the purchasing of transport and logistics services: an exploratory study', Proceedings of the 20th International Purchasing and Supply Education and Research Association (IPSERA) Conference, pp.1-14, Maastricht University.

Facanha, C. and Horvayh, A. (2005) 'Environmental assessment of logistics outsourcing', Journal of Management Engineering, Vol. 21, No. 27, pp.27-35.

Gonzalez-Benito, J. and Gonzalez-Benito, O. (2006) 'The role of stakeholder pressure and managerial values in the implementation of environmental logistics practices', International Journal of Production Research, Vol. 44, No. 7, pp.1353-1373.

Govindan, K., Kaliyan, M., Kannan, D. and Haq, A.N. (2013) 'Barriers analysis for green supply chain management implementation in Indian industries using analytic hierarchy process', International Journal of Production Economics [online] http://dx.doi.org/10.1016/j.ijpe.2013.08.018 (accessed 3 October 2013).

Guide, V.D.R., Jayaraman, V. and Srivastava, R. (1999) 'Production planning and control for remanufacturing: a state-of-the-art survey', Robotics and Computer-Integrated Manufacturing, Vol. 15, No. 3, pp.221-230.

Gungor, A. and Gupta, S.M. (1998) 'Disassembly sequence planning for products with defective parts in product recovery', Computers \& Industrial Engineering, Vol. 35, Nos. 1/2, pp.161-164.

Hall, J. (2000) 'Environmental supply chain dynamics', Journal of Cleaner Production, Vol. 8, No. 6, pp.455-471.

Hertz, S. and Alfredsson, M. (2003) 'Strategic development of third party logistics providers', Industrial Marketing Management, Vol. 32, No. 2, pp.139-149.

Hervani, A. and Helms, M. (2005) 'Performance measurement for green supply chain management', Benchmarking: An International Journal, Vol. 12, No. 4, pp.330-353.

Jayaraman, V., Patterson, R.A. and Rolland, E. (2003) 'The design of reverse distribution networks: models and solution procedures' European Journal of Operational Research, Vol. 150, No. 1, pp.128-149.

Jumadi, H. and Zailani, S. (2010) 'Integrating green innovations in logistics services towards logistics service sustainability: a conceptual paper', Environmental Research Journal, Vol. 4, No. 4, pp.261-271.

Klassen, R.D. and Johnson, P.F. (2004) 'The green supply chain', in New, S. and Westbrook, R. (Eds.): Understanding Supply Chains: Concepts, Critiques and Futures, Oxford University Press, New York, NY.

Lai, K. (2004) 'Service capability and performance of logistics service providers', Transportation Research Part E: Logistics and Transportation Review, Vol. 40, No. 5, pp.385-399.

Langella, I.M. and Zanoni, S. (2011) 'Eco-efficiency in logistics: a case study on distribution network design', International Journal of Sustainable Engineering, Vol. 4, No. 2, pp.115-126.

Large, R.O. and Gimenez Thomsen, C. (2011) 'Drivers of green supply management performance: evidence from Germany', Journal of Purchasing \& Supply Management, Vol. 17, No. 3, pp.176-184.

Lee, D.H. and Dong, M. (2009) 'Dynamic network design for reverse logistics operations under uncertainty', Transportation Research Part E: Logistics and Transportation Review, Vol. 45, No. 1, pp.61-71.

Lieb, K.J. and Lieb, R.C. (2010) 'Environmental sustainability in the third-party logistics (3PL) industry', International Journal of Physical Distribution \& Logistics Management, Vol. 40, No. 7, pp.524-533.

Lin, C.Y. and Ho, Y.H. (2008) 'An empirical study on logistics service providers' intention to adopt green innovations', Journal of Technology Management \& Innovation, Vol. 3, No. 1, pp.17-26. 
Marasco, A. (2008) 'Third-party logistics: a literature review', International Journal of Production Economics, Vol. 113, No. 1, pp.127-147.

Marchet, G., Perego, A. and Perotti, S. (2009) 'An exploratory study of ICT adoption in the Italian freight transportation industry', International Journal of Physical Distribution \& Logistics Management, Vol. 39, No. 9, pp.785-812.

McIntyre, K. and Smith, H.A. (1998) 'Logistics performance measurement and greening supply chains: diverging mindsets', International Journal of Logistics Management, Vol. 9, No. 1, pp.57-68.

McKinnon, A.C. (2010) 'Product-level carbon auditing of supply chains (environmental imperative or wasteful distraction?)', International Journal of Physical Distribution \& Logistics Management, Vol. 40, Nos. 1/2, pp.42-60.

Miles, M.B. and Huberman, A.M. (1994) Qualitative Data Analysis: An Expanded Sourcebook, Sage Publications, Thousand Oaks, CA.

Min, H. and Kim, I. (2012) 'Green supply chain research: past, present, and future', Logistics Research, Vol. 4, Nos. 1-2, pp.39-47.

Mudgal, R.K., Shankar, R., Talib, P. and Raj, T. (2010) 'Modelling the barriers of green supply chain practices: an Indian perspective', International Journal of Logistics Systems and Management, Vol. 7, No. 1, pp.81-107.

Muduli, K., Govindan, K., Barve, A. and Geng, Y. (2013) 'Barriers to green supply chain management in Indian mining industries: a graph theoretic approach', Journal of Cleaner Production, Vol. 47, pp.335-244.

Murphy, P.R. and Poist, R.F. (2000) 'Green logistics strategies: an analysis of usage patterns', Transportation Journal, Winter, Vol. 40, No. 2, pp.5-16.

Murphy, P.R. and Poist, R.F. (2003) 'Green perspectives and practices: a 'comparative logistics' study', Supply Chain Management: An International Journal, Vol. 8, No. 2, pp.122-131.

Perotti, S., Zorzini, M., Cagno, E. and Micheli, G.J.L. (2012) 'Green supply chain practices and company performance: the case of 3PLs in Italy', International Journal of Physical Distribution \& Logistics Management, Vol. 42, No. 7, pp.640-672.

Rai, D., Sodagar, B., Fieldson, R. and Hu, X. (2011) 'Assessment of CO2 emissions reduction in a distribution warehouse', Energy. Vol. 36, No. 4, pp.2271-2277.

Sarkis, J. (2003) 'A strategic decision framework for green supply chain management', Journal of Cleaner Production, Vol. 11, No. 4, pp.397-409.

Sarkis, J., Gonzalez-Torre, P. and Adenso-Diaz, B. (2010) 'Stakeholder pressure and the adoption of environmental practices: the mediating effect of training', Journal of Operations Management, Vol. 28, No. 2, pp.163-176.

Setaputra, R. and Mukhopadhyay, S.K. (2010) 'A framework for research in reverse logistics', International Journal of Logistics Systems and Management, Vol. 7, No. 1, pp.19-55.

Shi, Y. and Arthanari, T.S. (2011) 'Outsourcing purchasing services by third party logistics providers: a conceptual model', International Journal of Logistics Systems and Management, Vol. 10, No. 4, pp.398-419.

Smith, A. (2012) 'Green manufacturing in the packaging and materials industry: case study of small-to-medium sized corporate eco-friendly initiatives', International Journal of Logistics Systems and Management, Vol. 11, No. 4, pp.429-449.

Srivastava, S.K. (2007) 'Green supply-chain management: a state-of-the-art literature review', International Journal of Management Reviews, Vol. 9, No. 1, pp.53-80.

Sundarakani, B., de Souza, R., Goh, M., Wagner, S.M. and Manikandan, S. (2010) 'Modeling carbon footprints across the supply chain', International Journal of Production Economics, Vol. 128, No. 1, pp.43-50.

Testa, F. and Iraldo, F. (2010) 'Shadows and lights of GSCM (green supply chain management): determinants and effects of these practices based on a multi-national study', Journal of Cleaner Production, Vol. 18, pp.953-962. 
Vachon, S. (2007) 'Green supply chain practices and the selection of environmental technologies', International Journal of Production Research, Vol. 45, Nos. 18/19, pp.4357-4379.

Vachon, S. and Klassen, R.D. (2006) 'Extending green practices across the supply chain. The impact of upstream and downstream integration', International Journal of Operations \& Production Management, Vol. 26, No. 7, pp.795-821.

Voss, C., Tsikriktsis, N. and Frohlich, M. (2002) 'Case research in operations management', International Journal of Operations and Production Management, Vol. 22, No. 2, pp.195-219.

Walker, H., Di Sisto, L. and McBain, D. (2008) 'Drivers and barriers to environmental supply chain management practices: lessons from the public and private sectors', Journal of Purchasing \& Supply Management, Vol. 14, No. 1, pp.69-85.

Wanke, P., Arkader, R. and Hijjar, M.F. (2007) 'Logistics sophistication, manufacturing segments and the choice of logistics providers', International Journal of Operations \& Production Management, Vol. 27, No. 5, pp.542-559.

Wiengarten, F., Pagell, M. and Fynes, B. (2013) 'ISO 14000 certification and investments in environmental supply chain management practices: identifying differences in motivation and adoption levels between Western European and North American companies', Journal of Cleaner Production, Vol. 56, pp.18-28.

Wolf, C. and Seuring, S. (2010) 'Environmental impacts as buying criteria for third party logistical services', International Journal of Physical Distribution \& Logistics Management, Vol. 40, Nos. 1/2, pp.84-102.

Wu, H.J. and Dunn, S.C. (1995) 'Environmentally responsible logistics systems', International Journal of Physical Distribution \& Logistics Management, Vol. 25, No. 1, pp.20-38.

Xu, L., Mathiyazhagan, K. Govindan, K., Haq, A.N., Ramachandran, N.V. and Ashokkumar, A. (2013) 'Multiple comparative studies of green supply chain management: pressures analysis', Resources, Conservation and Recycling, Vol. 78, pp.26-35.

Yin, R. (2003) Case Study Research: Design and Methods, 3rd ed., Sage Publishing, Beverly Hills, CA.

Yin, R. (2009) Case Study Research: Design and Methods, Sage Publications, Thousand Oaks, CA.

Zailani, S., Amran, A. and Jumadi, H. (2011) 'Green innovation adoption among logistics service providers in Malaysia: an exploratory study on the managers' perceptions', International Business Management, Vol. 5, No. 3, pp.104-113.

Zhu, Q. and Sarkis, J. (2004) 'Relationships between operational practices and performance among early adopters of green supply chain management practices in Chinese manufacturing enterprises', Journal of Operations Management, Vol. 22, No. 2, pp.265-289.

Zhu, Q. and Sarkis, J. (2006) 'An inter-sectoral comparison of green supply chain management in China: drivers and practices', Journal of Cleaner Production, Vol. 14, No. 5, pp.472-486.

Zhu, Q. and Sarkis, J. (2007) 'The moderating effects of institutional pressures on emergent green supply chain practices and performance', International Journal of Production Research, Vol. 45, Nos. 18/19, pp.4333-4355.

Zhu, Q., Sarkis, J. and Lai, K. (2007) 'Green supply chain management: pressures, practices and performance within the Chinese automobile industry', Journal of Cleaner Production, Vol. 15, Nos. 11/12, pp.1041-1052.

Zhu, Q., Sarkis, J. and Lai, K. (2008) 'Green supply chain management implications for 'closing the loop", Transportation Research Part E: Logistics and Transportation Review, Vol. 44, No. 1, pp.1-18. 